Int. J. Dev. Biol. 64: 239-246 (2020)

https://doi.org/10.1387/ijdb.190148mm

\title{
Surviving nutritional deprivation during development: neuronal intracellular calcium signaling is critical
}

\author{
MEGHA and GAITI HASAN* \\ National Centre for Biological Sciences - TIFR, Bangalore, India
}

\begin{abstract}
Developing cells and tissues in a growing animal need to sense food quality and integrate this information with on-going time-bound developmental programs. The integration of metabolism with development requires cellular and systemic coordination. Work in our laboratory has focused on $\mathrm{Ca}^{2+}$ signaling arising from the release of $\mathrm{Ca}^{2+}$ stored in the endoplasmic reticulum (ER), which triggers store-operated $\mathrm{Ca}^{2+}$ entry. We describe a role for ER-store $\mathrm{Ca}^{2+}$ that operates at the cellular level in various classes of neurons, and eventually drives the systemic coordination required to survive and complete development under conditions of nutritional deprivation. In the model system Drosophila melanogaster, we have developed a paradigm to induce nutritional stress during the larval stage and used pupariation as a read-out for development. Applying the vast genetic tool kit available in Drosophila to this paradigm, we have uncovered novel roles for intracellular $\mathrm{Ca}^{2+}$ signaling in regulating neuronal activity, at the level of transcription in glutamatergic neurons, and translation in neuropeptidergic neurons. We find that such regulation of cellular processes is critical for integrating information across a neural circuit at multiple levels, starting from the point of sensing systemic and environmental levels of amino acids to finally connecting with neuropeptide secreting neurons, that communicate with the prothoracic gland, an organ that makes the key developmental hormone, ecdysone. This work underscores the importance of ERstore $\mathrm{Ca}^{2+}$ for neuronal health, with consequences for animal development.
\end{abstract}

KEY WORDS: $E R-C a^{2+}, I P_{3} R$, neuropeptide, malnutrition, glutamatergic, Drosophila

\section{Introduction}

Nutritious food is indispensable for proper animal development and growth. Two major processes, metabolism and development, need to converge at the systemic as well as cellular level, to complete the formation of a fully mature adult animal. Metabolic pathways are tuned by developmental cues to supply the necessary nutrients, while developmental pathways rely on metabolic pathways to fuel cellular differentiation and build organ systems. The two pathways are thus deeply entwined, and understanding how they are coordinated would help us understand how developing animals cope with sub-optimal nutrition. This is particularly relevant in a world where fetal and early childhood malnutrition is still rife. To investigate biological mechanisms that underpin nutrition and development, we need model systems. Drosophila melanogaster (abbreviated herein as Drosophila), the vinegar fly, has emerged as one such powerful model system for studying how dietary input is sensed and integrated with the developmental program (Boulan et al., 2015; Edgar, 2006; Mirth and Shingleton,
2012). We discuss our work in this area in the context of intracellular $\mathrm{Ca}^{2+}$ signaling.

\section{Drosophila as a model system to study how nutrition and development are linked}

A holometabolous insect, Drosophila exhibits four distinct life stages beginning from the egg $(\sim 24 \mathrm{~h})$, followed by three larval stages, L1, L2 and L3 ( 96 h), pupa ( 120 h) and adult (Fig.1). The egg and pupa are non-feeding stages during which development is fueled by stored nutrients. In contrast, the larva and adult are feeding stages, acutely sensitive to the availability of nutritious food. However, feeding patterns of the larva and adult differ significantly: larvae appear to feed continuously, except for brief periods of

\footnotetext{
Abbreviations used in this paper: Drosophila, Drosophila melanogaster; ER, endoplasmic reticulum; InR, insulin receptor; $\mathrm{IPC}$, insulin-producing cell; $\mathrm{IP}_{3} \mathrm{R}$, inositol 1,4,5-trisphosphate receptor, STIM, stromal interacting molecule; NR, nutrient restriction; NP, neuropeptide; NE, neuroendocrine; PG prothoracic gland.
}

*Address correspondence to: Gaiti Hasan. National Centre for Biological Sciences-TIFR, Bellary Road, Bangalore 560065, India.

Tel: +91 80 23336141. Fax: +91 80 23636662. E-mail: gaiti@ncbs.res.in - web: https://www.ncbs.res.in/faculty/gaiti - iD https://orcid.org/0000-0001-7194-383X

Submitted: 29 June, 2019; Accepted: 19 August, 2019.

ISSN: Online 1696-3547, Print 0214-6282 
moulting, whereas adults feed intermittently. Importantly, all growth occurs during the larval stages. Consequently, adult organismal size is determined by the final larval size. Because the systemic output in larvae is growth and maturation, whereas in adults it is survival and reproduction, it is likely that nutrient sensing pathways are tuned differently in the two stages. Thus, mechanisms derived from studying the effect of nutrition on adult flies may not necessarily be relevant or similarly important in larvae.

Laboratory fly food typically consists of the three major macronutrients: proteins, carbohydrates and lipids. In our laboratory, yeast serves as the major source of proteins, in addition to supplying precursors for sterol and lipid biosynthesis, whereas sugars and corn flour provide the bulk of the carbohydrates. While there are descriptions of completely synthetic fly media composed of amino acids, sugars and select micronutrients (Piper et al., 2013), in general, nutrient content can be altered by changing the proportion of yeast and sugar in the fly media. Thus protein deficiency is easily accomplished by reducing the amount of yeast.

Holometabolous insect larvae feed and reach an established critical weight after which starvation does not affect their ability to complete development (Robertson, 1963). For the laboratory grown $w 1118$ strain of Drosophila this happens $~ 8 \mathrm{~h}$ after transition to L3, with a weight checkpoint of $\sim 0.8 \mathrm{mg}$ (Koyama et al., 2014; Stieper et al., 2008). Starvation after reaching critical weight does not prevent development to pupae and further, to adults, except that a major cost is imposed on the size of the resulting adult. Changing the nutrient value of fly food after critical weight and before wandering stage, during which larvae crawl up the vial and stop feeding, yields a time window where integration of nutritional deficiency with development can be studied, in the absence of survival being a major issue (Fig. 1).

\section{Signaling mechanisms that integrate growth and development in Drosophila}

The key hormonal event in Drosophila that triggers development to the next stage and ultimately metamorphosis, is release of the steroid hormone ecdysone, from the prothoracic gland (PG) (Caldwell et al., 2005; Colombani et al., 2005; Mirth et al., 2005). The PG senses growth and coordinated development of various larval parts through multiple ways. Importantly, these pathways ultimately regulate pupariation timing by regulating ecdysone biosynthesis. Signaling pathways known to regulate PG function include insulin receptor (InR) signaling (Colombani et al., 2005; Mirth et al., 2005), TOR signaling (Layalle etal., 2008; Ohhara etal., 2017), TGF $\beta$ /activin pathway (McBrayer et al., 2007), PTTH peptide secreted by a pair of neurons in the brain (Rewitz et al., 2009), circulating hedgehog released by enterocytes (Rodenfels et al., 2014), dILP8 secreted by damaged imaginal discs (Colombani et al., 2012; Garelli et al., 2015) and more recently, circulating Dpp from peripheral tissues (Setiawan etal., 2018). Of these, the InR and TOR signaling pathways are perhaps the major ones that link nutrient availability to cellular growth (Britton et al., 2002; Layalle et al., 2008). Both pathways respond to local and systemic nutrient levels to promote protein synthesis and therefore, increase in cellular size and proliferation. Importantly, the molecular components of these signaling systems are conserved genetically and functionally between mammals and Drosophila (Das and Dobens, 2015).

InR activation is reliant on the availability of its ligand, insulin. Drosophila possess several insulin-like peptides (dILPs 1-8) of which the transcription and release of dILPs 2, 3 and 5 are known to be regulated by nutrient availability (Broughton et al., 2005; Kim and Neufeld, 2015; Okamoto and Nishimura, 2015; Slaidina et al., 2009). Unlike mammals though, insulin-like peptides in Drosophila are made in the central nervous system, in neurons called insulinproducing cells (IPCs) (Rulifson et al., 2002). IPCs release insulin peptides into circulation and also directly innervate the PG, thereby regulating ecdysone synthesis through non-cell autonomous as well as cell-autonomous mechanisms (Mirth et al., 2005). IPCs themselves appear to sense nutrient availability through a number of secreted factors that include, Neural Lazarillo (Pasco and Léopold, 2012), Upd2 (Rajan and Perrimon, 2012), CCHamide 2 (Sano et al., 2015), Eiger (Agrawal et al., 2016), Stunted (Delanoue et al., 2016) and Growth-Blocking Peptides (Koyama and Mirth, 2016), with the number of factors regulating IPCs set to grow. Together, the InR and TOR pathways are essential for integrating nutritional inputs such as sub-optimal protein conditions with growth and development. They operate at the level of peripheral tissues as well as on the $P G$. Such growth signaling pathways explain how nutritional input is converted to optimal cellular proliferation and growth. However they fail to explain how the animal is able to complete development in the absence of nutritional inputs, as in the case of Drosophila, where after reaching critical weight, larval to pupal development continues even in the absence of food. It is in this niche that our studies on ER-Store $\mathrm{Ca}^{2+}$ signaling have unexpectedly made a contribution.

\section{$I P_{3} \mathrm{R}$ regulated $\mathrm{Ca}^{2+}$ signaling in development and metabolism}

In the early 1990s, it became apparent that $\mathrm{Ca}^{2+}$ released from the ER is utilized by cells in order to respond to external stimuli

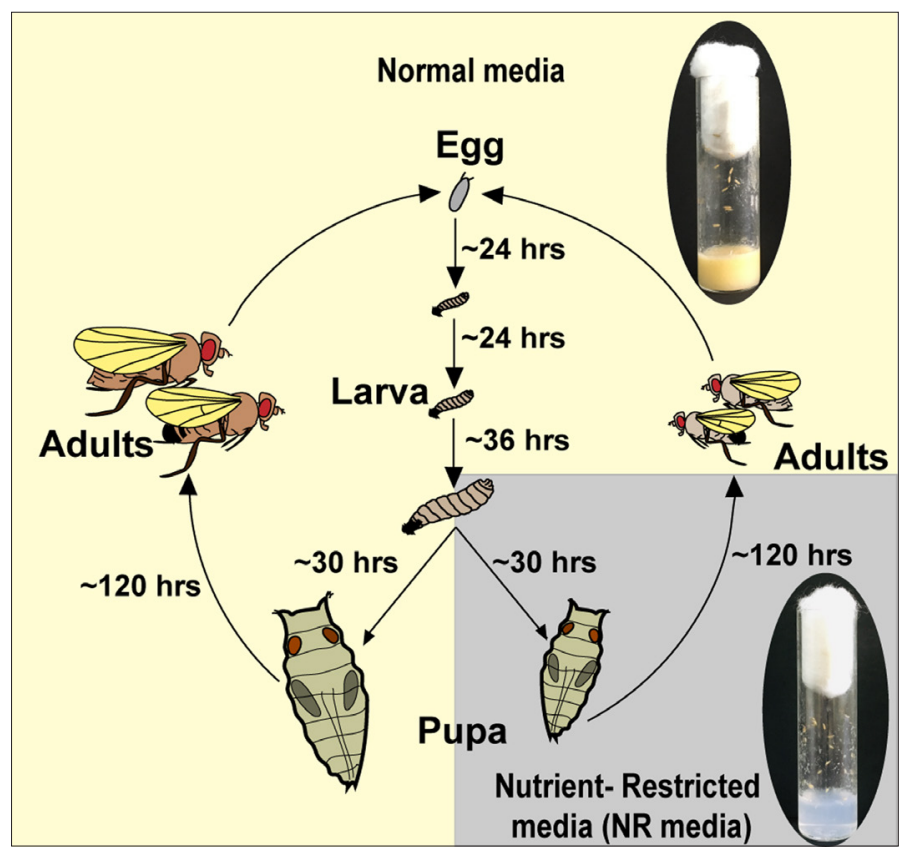

Fig. 1. Nutrient restriction (NR) assay during development. Drosophila larvae in mid-third instar ( 84 hours after egg laying) are taken from normal food conditions and moved to either $100 \mathrm{mM}$ Sucrose (NR media; inset) or back into normal media (inset). The number of pupae that develop are measured as a readout for development. 
(Clapham, 1995). Basal cytosolic $\mathrm{Ca}^{2+}$ levels are tightly maintained, at concentrations that are 100-500 fold lower than in the ER, as well as the extracellular milieu. This maintenance is enabled in part by an ATP-dependent channel on the endoplasmic reticulum (ER) called SERCA, which continuously pumps $\mathrm{Ca}^{2+}$ from the cytosol in to the ER (Clapham et al., 2007). Dynamic changes in the levels of cytosolic $\mathrm{Ca}^{2+}$ ions, either via release of $\mathrm{Ca}^{2+}$ from the ER or entry from the extracellular milieu, thus provides metazoan cells a mechanism to utilize $\mathrm{Ca}^{2+}$ as a second messenger to connect external stimuli to cellular function (Berridge et al., 2003; Clapham et al., 2007). The two known ligand-gated receptors on the ER that release ER-Store $\mathrm{Ca}^{2+}$ are the ryanodine receptor and the inositol 1,4,5-trisphosphate receptor $\left(\mathrm{IP}_{3} \mathrm{R}\right)$. Homologs of both intracellular $\mathrm{Ca}^{2+}$ release channels were identified in Drosophila by reverse genetic methods (Hasan and Rosbash, 1992). Subsequently, studies from our lab have focused exclusively on the $I_{3} R$, whose activation lies downstream of G-protein coupled receptors (GPCRs) of the $\mathrm{G} \alpha \mathrm{q}$ subtype. The $\mathrm{IP}_{3} \mathrm{R}$ is present in all metazoan cell types and given its pivotal role in gating ER-Store $\mathrm{Ca}^{2+}$ it is not surprising that it plays an important role in many different cellular functions. The temporality and amplitude of the stimuli, as well as the presence of cell-type specific proteins deliver outputs of intracellular $\mathrm{Ca}^{2+}$ signaling that vary according to cell-type. Thus there exists a breadth of cell signaling events where the $I_{3} R$ is important: fertilization, muscle contraction, neurotransmitter release, vesicle secretion, transcription and mitochondrial dynamics, amongst others (Mikoshiba, 2015). Here we focus on the participation of $\mathrm{IP}_{3} \mathrm{R}$ in cellular mechanisms that culminate in development and metabolic homeostasis.

Complete loss of the single $\mathrm{IP}_{3} \mathrm{R}$ gene (itpr) in Drosophilaresulted in early larval lethality. Hence, to investigate $I_{3} R$ function at later stages of development and in adults, an EMS-based mutagenesis screen was performed. This screen yielded several single itprpoint mutants which in homoallelic combinations resulted in larval lethality, while in some heteroallelic combinations yielded animals with varying levels of survival to adulthood (Joshi et al., 2004). The latter provided a genetic tool kit to study $\mathrm{IP}_{3} \mathrm{R}$ function at various stages of development. Genetic analysis showed that $\mathrm{IP}_{3}$-mediated $\mathrm{Ca}^{2+}$ release in the PG lies upstream of either ecdysone synthesis and/ or release, as feeding ecdysone could rescue development of $I P_{3} R$ mutants (Venkatesh and Hasan, 1997). This finding was validated independently in 2015, when a role for $I P_{3} R$ in releasing ecdysone from the PG was shown (Yamanaka et al., 2015).

Mammals have three isoforms of the $I_{3} R$ whose expression varies across tissue types. Mice lacking $I \mathrm{P}_{3} \mathrm{R} 1$ are mostly embryonic lethal (Matsumoto et al., 1996) with survivors ultimately succumbing to ataxia and seizures, while mice lacking $\mathrm{IP}_{3} \mathrm{R} 2 / 3$ die early due to poor secretion of digestive enzymes (Futatsugi et al., 2005). In humans, a number of mutations in the $I P_{3} R$ genes have been associated with disease (Terry et al., 2018) of which two that have parallels with mice studies are spinocerebellar ataxia (SCA), that affects motor coordination (van de Leemput et al., 2007), and Sjögren's Syndrome where salivary secretion is compromised (Teos et al., 2015). In regards to development, in mammals the earliest role for $\mathrm{IP}_{3} \mathrm{R}$ is in fertilization (Miyazaki et al., 1992; Miyazaki et al., 1993) followed by a role in specifying the dorso-ventral axis (Kume et al., 1997). While there is no single hormone responsible for coordinating overall development in vertebrates akin to ecdysone, the oscillatory pattern of $\mathrm{Ca}^{2+}$ release induced by $\mathrm{IP}_{3} \mathrm{R}$ activation is necessary for the secretion of hormones such as the gonadotropes follicle-stimulating hormone and luteinising hormone (Durán-Pastén and Fiordelisio, 2013), as well as oxytocin (Ludwig et al., 2002), whose downstream targets ultimately control sexual maturation, reproduction and social behavior. Thus, while the details vary from species to species, $\mathrm{IP}_{3} \mathrm{R}$ mediated $\mathrm{Ca}^{2+}$ release is important for the release of certain hormones and overall animal development.

In so far as nervous system development is concerned, an early study showed that $I \mathrm{P}_{3} \mathrm{R}$ is enriched in growth cones of neurons in the chick dorsal root ganglion and required there for neurite extension (Takei et al., 1998). In Drosophila, our heteroallelic $\mathrm{IP}_{3} \mathrm{R}$ mutants were useful in demonstrating a neuronal requirement for ${ }_{3}{ }_{3} R$ in viability (Joshi et al., 2004) and flight circuit maturation (Banerjee et al., 2006). These studies established physiological consequences of a loss in $I P_{3} R$ function in neurons during development. At that time, this line of investigation was particularly novel. A major focus of $\mathrm{Ca}^{2+}$ signaling in neurons was the characterization of activitydependent $\mathrm{Ca}^{2+}$ channels on the cell surface. That ER-Store $\mathrm{Ca}^{2+}$ too can contribute to, and modulate neuronal activity, was less well studied. Our group has pioneered this aspect of intracellular $\mathrm{Ca}^{2+}$ signaling and neuronal function to a significant extent.

At the cellular level, there is evidence that $I_{3} R$ regulates metabolism most notably by regulating the transfer of $\mathrm{Ca}^{2+}$ from the ER to the mitochondria (Cárdenas et al., 2010). The $I_{3} R$ is enriched at ER-Mitochondria contact sites and this coupling is important to allow for efficient transfer of $\mathrm{Ca}^{2+}$ from the ER to the mitochondria via the mitochondrial $\mathrm{Ca}^{2+}$ uniporter (Rizzuto et al., 2012). $\mathrm{Ca}^{2+}$ thus imported under basal conditions is required for the proper functioning of $\mathrm{Ca}^{2+-}$ dependent enzymes of the TCA cycle and in cancerous cells, is crucial for cell survival (Cardenas et al., 2016). At the systemic level, in mice hepatocytes, there is evidence that $I P_{3} R$, phosphorylated upon glucagon induction, leads to gluconeogenic gene expression, which ultimately contributes to systemic glucose homeostasis during fasting (Wang et al., 2012). This process is dysregulated in diabetes. Additionally a role for $\mathrm{IP}_{3} \mathrm{R}$ in regulating lipid droplet formation in mice hepatocytes in the context of fatty liver disease has been described (Feriod et al., 2017). The contribution of $I_{3} R$ to metabolism in neuronal cells, in tissue or primary culture, has been poorly explored. Our explorations in this area are detailed in the next section.

\section{Store-operated $\mathrm{Ca}^{2+}$ entry and neuronal function}

In 2005, the discovery of Stromal Interacting Molecule (STIM) an ER-Ca ${ }^{2+}$ sensor and in 2006 , of Orai, a calcium selective ion channel on the plasma membrane, ushered in the molecular study of intracellular $\mathrm{Ca}^{2+}$ signaling characterized as Store-operated $\mathrm{Ca}^{2+}$ entry (SOCE) (Hogan and Rao, 2015). When GPCRs activate the $I P_{3} R$, it leads to a release of $E R-\mathrm{Ca}^{2+}$ and concomitant decrease in ER-Ca ${ }^{2+}$ levels that is sensed by STIM (Fig. 2). Loss of ER-Ca ${ }^{2+}$ triggers a conformational change in STIM followed by STIM dimerization and the exposure of Orai-binding sites. Bound by STIM, the channel pore of Orai opens, leading to an influx of $\mathrm{Ca}^{2+}$ ions from the extracellular milieu into the cytosol. Increased cytosolic $\mathrm{Ca}^{2+}$ then leads to the activation of varied cell specific processes. Thus, SOCE offers cells yet another means to modulate the frequency and amplitude of $\mathrm{Ca}^{2+}$ signaling in the cytosol. Functional studies have shown a role for SOCE in cell types as different as immune cells (Shaw and Feske, 2012), various cancer cells (Vashisht et 
al., 2015) and neural progenitor cells (Gopurappilly et al., 2018; Somasundaram et al., 2014; Toth et al., 2016), with the list growing as new functions for STIM and Orai are discovered. Of note, both STIM and Orai have been implicated in systemic metabolism in the maintenance of lipid homeostasis; STIM in fat body of flies (Baumbach et al., 2014; Xu et al., 2019), and both STIM and Orai in mammals (Maus et al., 2017).

Capitalizing on single gene homologs of STIM and Orai in the Drosophila genome, our lab demonstrated that $\mathrm{IP}_{3}$-mediated $\mathrm{Ca}^{2+}$ release is followed by SOCE in Drosophilaneurons (Venkiteswaran and Hasan, 2009). Importantly, by using flight as a behavioral readout, we showed that SOCE in neurons is required for maturation of the flight neuronal circuit during pupal development (Agrawal et al., 2010; Venkiteswaran and Hasan, 2009). Thus, not only do Drosophila neurons display SOCE signaling, but also, this signaling has functional consequences during neural development. Next we delved into the molecular basis of how neuronal function is regulated by SOCE. A transcriptomic screen in pupal brains identified many genes that are regulated by STIM and are required for flight circuit maturation (Richhariya et al., 2017). We are now exploring how these molecular changes differ in various neuronal subtypes, and how they affect cellular output both at the level of the neuron, and in the neural circuit required for flight behavior.

Unlike the investigations on flight circuit maturation, our investigations on SOCE in the context of nutrition and development were somewhat serendipitous. Adult flies carrying hypomorphic mutations for the $\mathrm{IP}_{3} \mathrm{R}$ exhibit hyperphagia and altered lipid metabolism, with systemic consequences such as increased weight and higher

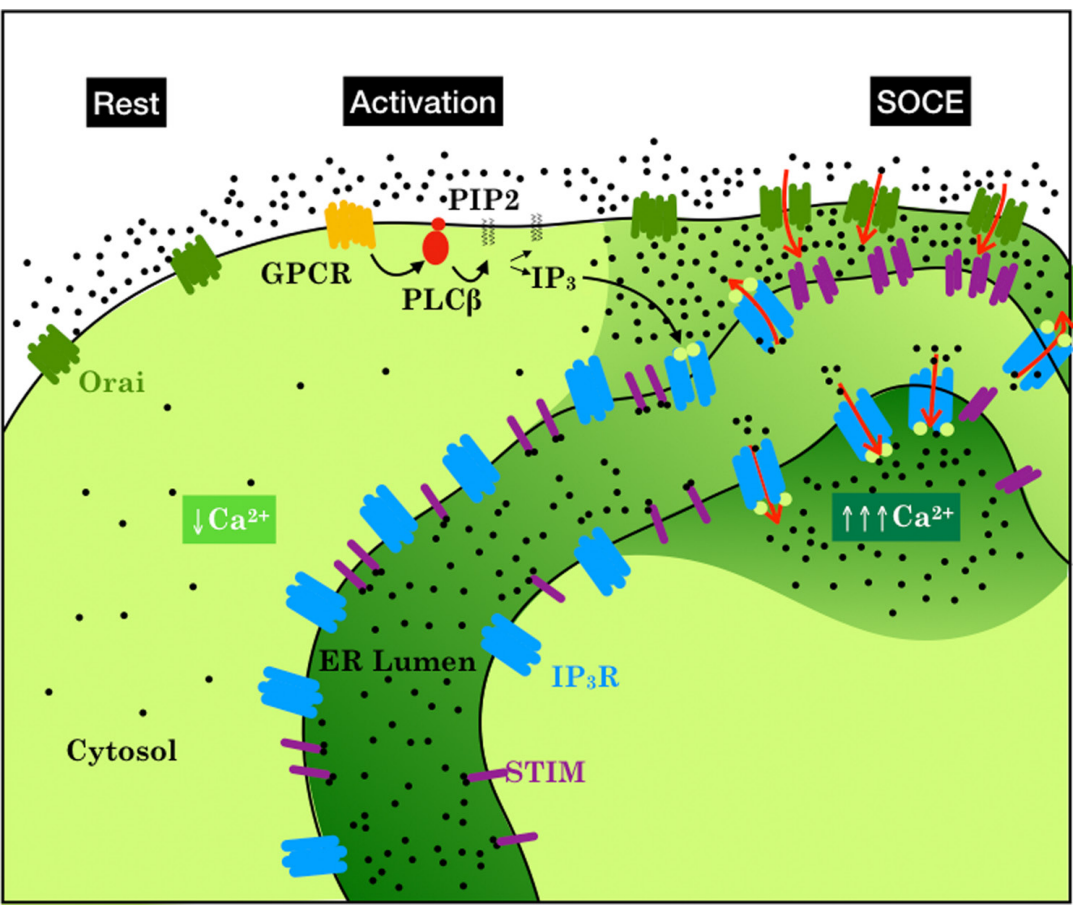

Fig. 2. SOCE (Store-operated $\mathrm{Ca}^{2+}$ entry) in neurons. At rest, cytosolic $\mathrm{Ca}^{2+}$ levels are low and range between 100-400nM. Generation of $I P_{3^{\prime}}$ downstream of GPCR activation, leads to opening of the $I P_{3} R$ channel and release of ER-store $\mathrm{Ca}^{2+}$. A drop in $E R$ $\mathrm{Ca}^{2+}$ concentration causes STIM to dimerize, cluster at ER-PM junctions and bind to the plasma-membrane localized SOCE channel Orai. Binding of STIM with Orai leads to an influx of $\mathrm{Ca}^{2+}$ from the extracellular milieu. Increased cytosolic $\mathrm{Ca}^{2+}$ regulates translation in peptidergic neurons. In glutamatergic neurons it directly modulates neuronal activity and in addition, regulates transcription leading to long-term changes in activity of neural circuits. Regulation of basic cellular processes and neuronal function by intracellular calcium signaling underpins the ability of larvae to pupariate under nutrient stress. levels of Triacylglycerides (TAGs) (Subramanian et al., 2013). To understand if adult metabolism could be reset by manipulating the nutritional input of larvae, $\mathrm{IP}_{3} \mathrm{R}$ mutants were subjected to nutrient restriction (NR) in the late larval stage. We devised an NR paradigm that involved shifting mid to late stage $3^{\text {rd }}$ instar larvae to a protein deficient diet consisting of $100 \mathrm{mM}$ Sucrose, up until pupariation (Fig. 1). While control larvae can successfully complete development in the NR paradigm, surprisingly, $\mathrm{IP}_{3} \mathrm{R}$ mutant larvae cannot. This despite the fact that both control and mutant larvae were placed under NR after crossing critical weight, and much after critical time, beyond which the development of Drosophila typically becomes independent of food quality. Why do itprmutants fail to pupariate under NR conditions? It is this question that led to insights on the neuronal requirement of intracellular $\mathrm{Ca}^{2+}$ signaling and SOCE for development, in the NR paradigm.

\section{Neuronal control of development under conditions of nutritional stress}

Because key components of $\mathrm{IP}_{3}$ signaling and SOCE, like the $\mathrm{IP}_{3} \mathrm{R}, \mathrm{STIM}$ and Orai, are expressed ubiquitously in multiple cell types, the cellular basis of pupariation needed further investigation. The GAL4-UAS system (Brand and Perrimon, 1993) was used to perform a genetic screen in which GAL4s specific to various organs and cell types were employed to reduce $\mathrm{IP}_{3} \mathrm{R}$ expression using a transgenic RNAi construct referred to as UAS-itprIR (Agrawal et al., 2010). The resulting larvae were tested for pupariation on NR. This screen identified a strong requirement for $\mathrm{IP}_{3} \mathrm{R}$ in neuronal tissues and as expected in the PG, for larval to pupal development on an NR diet (Jayakumar et al., 2016; Megha and Hasan, 2017). Based on the strength of the NR phenotype observed we focused on two neuronal subtypes, the neuroendocrine (NE) cells and a subset of glutamatergic neurons of the ventral nerve cord referred to as VGN6341 neurons, for further study.

Neuroendocrine (NE) cells produce neuropeptides (NPs), a class of signaling agents, which can act either locally on neural circuits or systemically on other organs, to ultimately regulate a large number of behaviors and metabolism (Nassel and Winther, 2010). The broad role played by NPs and the poor characterization of SOCE molecules in modulating NE cell activity, fueled our interest in this neuronal subtype. We observed that reducing SOCE activity by manipulating $\mathrm{IP}_{3} \mathrm{R}$, STIM or Orai in NE cells reduced pupariation on NR (Megha and Hasan, 2017). A parallel observation at the systemic level was that $I P_{3} R$ mutants were sensitive to levels of dietary protein and displayed lower protein/TAG ratio suggesting a protein metabolism defect. Because InR and TOR signaling pathways are known regulators of protein metabolism we combined the two observations to design a genetic experiment to test if molecules of the InR and/or TOR pathway compensated 
for $\mathrm{IP}_{3} \mathrm{R}$ function. Indeed, over-expression of either $\mathrm{InR}$ or TOR signaling in NE cells was sufficient to rescue pupariation of $I_{3} R$ mutants on NR, as well as systemic protein/TAG ratio. Conversely, over-expression of $\mathrm{IP}_{3} \mathrm{R}$ could overcome loss of InR signaling in NE cells. These experiments led to the hypothesis that the InR and $I P_{3} R$ pathways are functionally complementary in NE cells. To test this, we measured levels of protein translation in NE cells in various genetic conditions. $\mathrm{IP}_{3} \mathrm{R}$ mutant $\mathrm{NE}$ cells displayed decreased protein translation and this could be restored to normal levels by the over-expression of wild type $I_{3} R$. Together, these experiments describe a novel role for $\mathrm{IP}_{3} \mathrm{R}$ in protein translation in NE cells and hence as an important determinant of development on NR (Megha and Hasan, 2017). Unlike InR or TOR pathways, the $I P_{3} R$ signaling pathway is nutrient-independent. We speculate that this type of nutrient-independent control of protein translation is required in NE cells, perhaps because peptides made by these neurons are required in NR conditions to coordinate development. Reduced nutrient availability during NR likely reduces the activity of $\ln R$ and TOR pathways in NE cells and a positive nutrient-independent regulator of protein translation, such as $I_{3} R$, is required to maintain a certain level of protein translation and therefore, peptide levels. This speculation was based on a study of how neural stem cells (NSCs), which usually rely on InR and TOR signaling to exit quiescence and begin proliferation, continue to do so under NR conditions by switching to another ligand-receptor system that helps to maintain active signaling downstream of $\ln R$ and TOR (Cheng et al., 2011).

Each NE neuron secretes one or more distinct neuropeptide (NP) and together the NE subset tested in the previous project make at least 20 known NPs. To understand which neuropeptide(s) made in these cells is required in the context of SOCE to survive NR a curated genetic screen was performed. This screen yielded several candidate NPs, of which we decided to pursue Corazonin ( $\mathrm{Crz}$ ) and short Neuropeptide F (sNPF). Crz and SNPF are co-expressed in small set of neurons ( 6; Dorsolateropeptidergic; DLPs) in the larval brain, providing a system where STIM's role in cellular neuropeptide biology could be easily studied. Immunohistochemistry and mass spectrometry revealed that loss of STIM perturbed peptide levels in DLP neurons: in the fed state, peptide levels were increased, while upon starvation, they remained unaltered while in the control they increased. Additional genetic experiments suggest two possible points at which STIM acts on neuropeptides - secretion and synthesis. Ultimately, loss of STIM in DLPS, resulted in reduced systemic Crz signaling which correlated with an inability of larvae to survive nutritional stress (Megha et al., 2018).

\section{Nutrient restriction stimulates a neuropeptide dependent glutamatergic neuron-insulin-producing cell circuit for stimulating ecdysone synthesis}

In addition to regulating the synthesis and secretion of neuropeptides, experiments on a set of glutamatergic interneurons (the VGN6341 neurons) in the context of development on NR have established a role for neuropeptide and acetylcholine stimulated intracellular $\mathrm{Ca}^{2+}$ signaling through the $\mathrm{IP}_{3} \mathrm{R}$ in regulating neuronal gene transcription as well as neuronal activity (Jayakumar et al., 2016). VGN6341 neurons are located in the mid-ventral ganglion and $\mathrm{IP}_{3} \mathrm{R}$ activity in this glutamatergic interneuron subset was found to be necessary for survival on NR. Because $I P_{3} R$ operates downstream of GPCRs, a genetic screen was conducted to identify receptors on VGN6341 neurons required in the NR paradigm. Interestingly, amongst the receptors identified, the largest class belonged to neuropeptide receptors, further underscoring the importance of neuropeptides to animal development under NR conditions. In VGN6341 neurons neuropeptides stimulate specific aspects of intracellular $\mathrm{Ca}^{2+}$ signaling (see next paragraph). Additionally, the identification of muscarinic acetylcholine receptor (mAChR) suggested that cholinergic neurons were involved in transmitting NR information to VGN6341 neurons. Here, the genetic toolkit available to Drosophila researchers came handy; by testing a series of GAL4 lines known to mark various subsets of cholinergic neurons, we identified multidendritic sensory cholinergic neurons (MSNs) located on the larval body wall as the source of NR sensing. Subsequently, we discovered that MSNs can sense nutrients directly through the amino acid transporter slimfastand also respond to the loss of essential amino acids, including arginine, in the food media (Jayakumar et al., 2018). The MSNs convey this information to the glutamatergic neuronal subset covered by VGN6341-GAL4. A role for glutamatergic neurons in nutrient sensing is novel and required better understanding. Mapping of neuronal projections from the VGN6341 neurons identified projections from the VNC that travel up to the larval brain lobes and reach the medial neurosecretory cells (mNSCs), a set of NE cells that make and secrete a number of NPs, and includes the IPCs. Others have demonstrated that ILPS secreted from the IPCs stimulates ecdysone synthesis from the PG (Colombani et al., 2005; Mirth et al., 2005). Thus, glutamatergic neurons in the ventral ganglion receive cholinergic inputs from the MSNs present on the larval body wall and transmit this information to the mNSCs in the brain. Signals received by the mNSCs stimulate ILP synthesis and/or release under protein-deprived conditions. Overall, this neural circuit up-regulates the transcription of ecdysone synthesizing genes in the PG (Jayakumar et al., 2016).

In addition to the circuit, we examined how ${ } P_{3} R$ regulates activity in the VGN6341 neurons using ex-vivo brain preparations (Jayakumar et al., 2018). Oscillating and long lasting $\mathrm{Ca}^{2+}$ signals were produced in the glutamatergic neurons upon loss of arginine that were dependent on intracellular $\mathrm{Ca}^{2+}$ signaling. Whereas initiation of $\mathrm{Ca}^{2+}$ signals required cholinergic stimulation of the $m A c h R$, subsequent oscillations depended on NP receptor activation. To understand how neuronal properties were altered in $\mathrm{IP}_{3} \mathrm{R}$ mutants, differentially regulated genes were identified by an RNAseq and validated in fluorescent activator-sorted VGN6341 neurons. Many genes coding for voltage-gated ion channels including NaCP60E (Sodium channel), Hk, eag (Potassium channel), cacophony, Caaplha1D (Calcium channels) were down-regulated in the $\mathrm{IP}_{3} \mathrm{R}$ mutants as well as upon $d S T I M$ and IP3R knockdown. Changes in intracellular $\mathrm{Ca}^{2+}$ signaling thus modulate neuronal receptivity to acetylcholine and neuropeptides, and also leads to chronic changes in gene expression that can alter neuronal properties of excitability.

Together, these studies show that intracellular $\mathrm{Ca}^{2+}$ signaling plays an important and necessary role in regulating neuronal activity at the level of transcription as well as translation (Fig 2). Importantly, this regulation appears to be a fail-safe mechanism because it does not affect development when sufficient food resources are present. In times of nutritional stress, after the animal has sufficient internal resources to reach adult hood, this neuronal regulation takes on an important role. It ensures that nutrient-sensitive circuits and neuropeptidergic outputs continue to 
adequately provide measures to over-ride loss of nutrition signals and allow development to proceed.

\section{Future studies}

There are two main directions we see emerging from these studies: further identification of molecular changes that are brought about by intracellular $\mathrm{Ca}^{2+}$ signaling in neurons during neural circuit maturation, and adapting the NR paradigm to ask questions that resonate with public health investigations on malnutrition.

In psychiatric disorders with developmental origins such as autism, no single gene correlates with major disease risk. Instead, the emerging hypothesis is that a change in balance of excitatory and inhibitory stimuli experienced by developing neural circuits might underlie disease manifestation (Nelson and Valakh, 2015). We propose that intracellular $\mathrm{Ca}^{2+}$ signaling can be contributory in maintaining a balance for such activation and silencing of neurons. Cumulatively, our work in Drosophila shows that intracellular $\mathrm{Ca}^{2+}$ signaling can perturb basic cellular processes in neurons, such as translation and transcription, providing broad mechanisms by which this balance may be controlled. Transcriptomic analysis of Drosophila pupal neurons has already provided us a list of genes whose expression is sensitive to intracellular $\mathrm{Ca}^{2+}$ signaling (Richhariya et al., 2017). Interestingly, mutations in rala, a modulator of synaptic vesicle release validated from this screen (Richhariya et al., 2018), were recently identified as a genetic cause of intellectual disability (Hiatt et al., 2018). Transcriptional regulation by intracellular calcium signaling also sets the stage to uncover how such gene expression changes are regulated: either directly perhaps by a common transcription factor whose activity is controlled by cytosolic $\mathrm{Ca}^{2+}$ levels, or other mechanisms of gene expressions, such as chromatin remodeling. The latter is suggested by another gene identified in the transcriptomic screen for SOCE-regulated genes, dSet2, a gene encoding a histone methyltransferase.

Scaling from these molecular studies to understanding how nutrition can re-program neurons and therefore behavior, requires a whole organism approach for which Drosophila is ideally suited. The molecular players involved in development as well as metabolism are strongly conserved between humans and animals, including Drosophila. There exist multiple classes of genetic tools that allow for scaling from molecules to organ systems to individuals, in Drosophila. Moreover, it is relatively cost-effective as compared to mammalian model organisms, easy to breed and its dietary input can be easily manipulated. We are at present characterizing the locomotory behavior (flight, walking, climbing, daily activity rhythms) in flies that have been subject to early life protein deprivation as well investigating their metabolism in response to a variety of diets in adulthood. These experiments will hopefully help identify adult phenotypes that correlate with early life nutritional stress, whose molecular basis can then be investigated by working on neural circuits described for these phenotypes. In humans, severe to moderate protein deficiency during childhood is associated with growth retardation, along with long-term consequences for mental health and metabolism. The molecular basis of how early life nutrition manifests into disease and health risks later in adult life is not well understood. Given the high prevalence of protein malnutrition in India, model systems to pursue this biology are therefore, the need of the hour, a niche that Drosophila may fulfil.

\section{Acknowledgements}

We would like to thank Steffy B Manjila for assistance with artwork. Megha is an Early Career Fellow whose research is funded by the Wellcome Trust/ DBT India Alliance.

\section{References}

AGRAWAL N, DELANOUE R, MAURI A, BASCO D, PASCO M, THORENS B, LEOPOLD P (2016). The Drosophila TNF Eiger Is an Adipokine that Acts on Insulin-Producing Cells to Mediate Nutrient Response. Cell Metab 23: 675-684.

AGRAWAL N, VENKITESWARAN G, SADAF S, PADMANABHAN N, BANERJEE S, HASAN G (2010). Inositol 1,4,5-trisphosphate receptor and dSTIM function in Drosophila insulin-producing neurons regulates systemic intracellular calcium homeostasis and flight. $J$ Neurosci 30: 1301-1313.

BANERJEE S, JOSHIR, VENKITESWARAN G, AGRAWALN, SRIKANTHS, ALAM F, HASAN G (2006). Compensation of inositol 1,4,5-trisphosphate receptor function by altering sarco-endoplasmic reticulum calcium ATPase activity in the Drosophila flight circuit. J Neurosci 26: 8278-8288.

BAUMBACH J, HUMMELP, BICKMEYERI, KOWALCZYK KMM, FRANK M, KNORR K, HILDEBRANDT A, RIEDEL D, JÄCKLE H, KÜHNLEIN RP, JACKLE H, KUHNLEIN RP (2014). A Drosophila in vivo screen identifies store-operated calcium entry as a key regulator of adiposity. Cell Metab 19: 331-343.

BERRIDGE MJ, BOOTMAN MD, RODERICK HL (2003). Calcium signalling: dynamics, homeostasis and remodelling. Nat Rev Mol Cell Biol 4: 517.

BOULAN L, MILAN M, LEOPOLD P (2015). The Systemic Control of Growth. Cold Spring Harb Perspect Biol 7. 7(12). pii: a019117

BRAND AH, PERRIMON N (1993). Targeted gene expression as a means of altering cell fates and generating dominant phenotypes. Development 118: 401-415.

BRITTON JS, LOCKWOOD WK, LI L, COHEN SM, EDGAR BA (2002). Drosophila's insulin/PI3-kinase pathway coordinates cellular metabolism with nutritional conditions. Dev Cell 2: 239-249.

BROUGHTON SJ, PIPER MD, IKEYA T, BASS TM, JACOBSON J, DRIEGE Y, MARTINEZ P, HAFEN E, WITHERS DJ, LEEVERS SJ, PARTRIDGE L (2005). Longer lifespan, altered metabolism, and stress resistance in Drosophila from ablation of cells making insulin-like ligands. Proc Natl Acad Sci USA 102: 3105-3110.

CALDWELL PE, WALKIEWICZ M, STERN M (2005). Ras activity in the Drosophila prothoracic gland regulates body size and developmental rate via ecdysone release. Curr Biol 15: 1785-1795.

CÁRDENAS C, MILLER RA, SMITH I, BUI T, MOLGÓ J, MÜLLER M, VAIS H, CHEUNG K-H, YANG J, PARKER I, THOMPSON C, BIRNBAUM M, HALLOWS KR, FOSKETT JK (2010). Essential Regulation of Cell Bioenergetics By Constitutive InsP(3) Receptor $\mathrm{Ca}(2+)$ Transfer to Mitochondria. Cell 142: 270-283.

CARDENAS C, MULLER M, MCNEAL A, LOVY A, JANA F, BUSTOS G, URRA F, SMITH N, MOLGO J, DIEHL JA, RIDKY TW, FOSKETT JK (2016). Selective Vulnerability of Cancer Cells by Inhibition of $\mathrm{Ca}(2+)$ Transfer from Endoplasmic Reticulum to Mitochondria. Cell Rep 15: 219-220.

CHENG LY, BAILEY AP, LEEVERS SJ, RAGAN TJ, DRISCOLL PC, GOULD AP (2011). Anaplastic lymphoma kinase spares organ growth during nutrient restriction in Drosophila. Cell 146: 435-447.

CLAPHAM DE (1995). Calcium signaling. Cell 80: 259-268.

CLAPHAM DE, YEROMIN AV, ZHANG XH, YU Y, SAFRINA O, PENNA A, ROOS J, STAUDERMAN KA, CAHALAN MD, TAKEMORI H, AL. et (2007). Calcium signaling. Cell 131: 1047-1058.

COLOMBANI J, ANDERSEN DS, LEOPOLD P (2012). Secreted peptide Dilp8 coordinates Drosophilatissue growth with developmental timing. Science 336:582-585.

COLOMBANI J, BIANCHINI L, LAYALLE S, PONDEVILLE E, DAUPHIN-VILLEMANT C, ANTONIEWSKI C, CARRE C, NOSELLI S, LEOPOLD P (2005). Antagonistic actions of ecdysone and insulins determine final size in Drosophila. Science 310: $667-670$.

DAS R, DOBENS LL (2015). Conservation of gene and tissue networks regulating insulin signalling in flies and vertebrates. Biochem Soc Trans 43.

DELANOUE R, MESCHI E, AGRAWAL N, MAURI A, TSATSKIS Y, MCNEILL H, LÉOPOLD P (2016). Drosophila insulin release is triggered by adipose Stunted ligand to brain Methuselah receptor. Science (80-) 353: 1553 LP - 1556. 
DURÁN-PASTÉN ML, FIORDELISIOT (2013). GnRH-Induced Ca2+Signaling Patterns and Gonadotropin Secretion in Pituitary Gonadotrophs. Functional Adaptations to Both Ordinary and Extraordinary Physiological Demands. Front Endocrino/4:127.

EDGAR BA (2006). How flies get their size: genetics meets physiology. Nat Rev Genet 7: 907-916.

FERIOD CN, OLIVEIRA AG, GUERRA MT, NGUYEN L, RICHARDS KM, JURCZAK MJ, RUAN H-B, CAMPOREZ JP, YANG X, SHULMAN GI, BENNETT AM, NATHANSON MH, EHRLICH BE (2017). Hepatic Inositol 1,4,5 Trisphosphate Receptor Type 1 Mediates Fatty Liver. Hepatol Commun 1: 23-35.

FUTATSUGI A, NAKAMURA T, YAMADA MK, EBISUI E, NAKAMURA K, UCHIDA K, KITAGUCHI T, TAKAHASHI-IWANAGA H, NODA T, ARUGA J, MIKOSHIBA K (2005). IP3 receptor types 2 and 3 mediate exocrine secretion underlying energy metabolism. Science (80-) 309: 2232-2234.

GARELLI A, HEREDIA F, CASIMIRO AP, MACEDO A, NUNES C, GARCEZ M, DIAS ARM, VOLONTE YA, UHLMANN T, CAPARROS E, KOYAMA T, GONTIJO AM (2015). Dilp8 requires the neuronal relaxin receptor Lgr3 to couple growth to developmental timing. Nat Commun 6: 8732.

GOPURAPPILLY R, DEB BK, CHAKRABORTY P, HASAN G (2018). Stable STIM1 Knockdown in Self-Renewing Human Neural Precursors Promotes Premature Neural Differentiation. Front Mol Neurosci 11: 178.

HASAN G, ROSBASHM (1992). Drosophila homologs of two mammalian intracellular $\mathrm{Ca}(2+)$-release channels: identification and expression patterns of the inositol 1,4,5-triphosphate and the ryanodine receptor genes. Development 116:967-975.

HIATTSM, NEU MB, RAMAKERRC, HARDIGANAA, PROKOP JW, HANCAROVAM, PRCHALOVAD, HAVLOVICOVAM, PRCHALJ, STRANECKY V, etal., (2018). De novo mutations in the GTP/GDP-binding region of RALA, a RAS-like small GTPase, cause intellectual disability and developmental delay. PLOS Genet 14: e1007671.

HOGAN PG, RAOA (2015). Store-operated calcium entry: Mechanisms and modulation. Biochem Biophys Res Commun 460: 40-49.

JAYAKUMAR S, RICHHARIYA S, DEB BK, HASAN G (2018). A Multicomponent Neuronal Response Encodes the Larval Decision to Pupariate upon Amino Acid Starvation. J Neurosci 38: 10202-10219.

JAYAKUMAR S, RICHHARIYA S, REDDY OV, TEXADA MJM, HASAN G, RICHARIYA S, REDDY VO, TEXADA MJM, HASAN G (2016). Drosophila larval to pupal switch under nutrient stress requires IP3R/Ca2+ signalling in glutamatergic interneurons. Elife 5: e17.

JOSHIR, VENKATESHK, SRINIVASR, NAIRS, HASAN G (2004). Genetic dissection of itpr gene function reveals a vital requirement in aminergic cells of Drosophila larvae. Genetics 166: 225-236.

KIM J, NEUFELD TP (2015). Dietary sugar promotes systemic TOR activation in Drosophilathrough AKH-dependent selective secretion of Dilp3. Nat Commun 6:6846.

KOYAMA T, MIRTH CK (2016). Growth-Blocking Peptides As Nutrition-Sensitive Signals for Insulin Secretion and Body Size Regulation. PLOS Biol 14: e1002392.

KOYAMA T, RODRIGUES MA, ATHANASIADIS A, SHINGLETON AW, MIRTH CK (2014). Nutritional control of body size through FoxO-Ultraspiracle mediated ecdysone biosynthesis Ed. H McNeill. Elife 3: e03091.

KUME S, MUTO A, INOUE T, SUGA K, OKANO H, MIKOSHIBA K (1997). Role of inositol 1,4,5-trisphosphate receptor in ventral signaling in Xenopus embryos. Science 278: 1940-1943.

LAYALLE S, ARQUIER N, LEOPOLD P (2008). The TOR pathway couples nutrition and developmental timing in Drosophila. Dev Cell 15: 568-577.

VAN DE LEEMPUT J, CHANDRAN J, KNIGHT MA, HOLTZCLAW LA, SCHOLZ S, COOKSON MR, HOULDEN H, GWINN-HARDY K, FUNG H-C, LIN X, et al., (2007). Deletion at ITPR1 underlies ataxia in mice and spinocerebellar ataxia 15 in humans. PLoS Genet 3: e108.

LUDWIG M, SABATIER N, BULLPM, LANDGRAF R, DAYANITHI G, LENG G (2002). Intracellular calcium stores regulate activity-dependent neuropeptide release from dendrites. Nature 418: 85-89.

MEGHA, CHRISTIAN WEGENER and GAITI HASAN (2019) Neuropeptides required for Drosophila development under nutritional stress are regulated by the ER-Ca2+ sensor STIM. PLoS One. 14(7):e0219719.

MATSUMOTO M, NAKAGAWA T, INOUE T, NAGATA E, TANAKA K, TAKANO H, MINOWA O, KUNO J, SAKAKIBARA S, YAMADA M, YONESHIMA H, MIYAWAKI A, FUKUUCHI Y, FURUICHIT, OKANO H, MIKOSHIBAK, NODA T (1996). Ataxia and epileptic seizures in mice lacking type 1 inositol 1,4,5-trisphosphate receptor. Nature 379: 168-171.
MAUS M, CUK M, PATEL B, LIAN J, OUIMET M, KAUFMANN U, YANG J, HORVATH R, HORNIG-DO H-T, CHRZANOWSKA-LIGHTOWLERS ZM, MOORE KJ, CUERVO AM, FESKE S (2017). Store-Operated Ca(2+) Entry Controls Induction of Lipolysis and the Transcriptional Reprogramming to Lipid Metabolism. Cell Metab 25: 698-712.

MCBRAYER Z, ONO H, SHIMELL M, PARVY JP, BECKSTEAD RB, WARREN JT, THUMMEL CS, DAUPHIN-VILLEMANT C, GILBERT LI, O'CONNOR MB (2007). Prothoracicotropic Hormone Regulates Developmental Timing and Body Size in Drosophila. Dev Cell 13: 857-871.

MEGHA, HASAN G (2017). IP3R-mediated Ca2+ release regulates protein metabolism in Drosophila neuroendocrine cells: implications for development under nutrient stress. Development 144: 1484-1489.

MIKOSHIBA K (2015). Role of IP3 receptor signaling in cell functions and diseases. Adv Biol Regul 57: 217-227.

MIRTH C, TRUMAN JW, RIDDIFORD LM (2005). The role of the prothoracic gland in determining critical weight for metamorphosis in Drosophila melanogaster. Curr Biol 15: 1796-1807.

MIRTH CK, SHINGLETONAW (2012). Integrating body and organ size in Drosophila: Recent advances and outstanding problems. Front Endocrinol 3:49.

MIYAZAKI S, SHIRAKAWA H, NAKADA K, HONDA Y (1993). Essential role of the inositol 1,4,5-trisphosphate receptor/Ca2+ release channel in $\mathrm{Ca} 2+$ waves and Ca2+ oscillations at fertilization of mammalian eggs. Dev Biol 158: 62-78.

MIYAZAKI S, YUZAKI M, NAKADA K, SHIRAKAWA H, NAKANISHI S, NAKADE S, MIKOSHIBA K (1992). Block of Ca2+ wave and Ca2+ oscillation by antibody to the inositol 1,4,5-trisphosphate receptor in fertilized hamster eggs. Science 257: 251-255.

NASSEL DR, WINTHER AM (2010). Drosophila neuropeptides in regulation of physiology and behavior. Prog Neurobiol 92: 42-104.

NELSON SB, VALAKHV (2015). Excitatory/Inhibitory Balance and Circuit Homeostasis in Autism Spectrum Disorders. Neuron 87: 684-698.

OHHARA Y, KOBAYASHI S, YAMANAKAN (2017). Nutrient-Dependent Endocycling in Steroidogenic Tissue Dictates Timing of Metamorphosis in Drosophila melanogaster. PLoS Genet 13: e1006583.

OKAMOTO N, NISHIMURA T (2015). Signaling from Glia and Cholinergic Neurons Controls Nutrient-Dependent Production of an Insulin-like Peptide for Drosophila Body Growth. Dev Cell 35: 295-310.

PASCO MY, LÉOPOLDP (2012). High Sugar-Induced Insulin Resistance in Drosophila Relies on the Lipocalin Neural Lazarillo. PLoS One 7: e36583.

PIPER MDW, BLANC E, LEITÃO-GONÇALVES R, YANG M, HE X, LINFORD NJ, HODDINOTT MP, HOPFEN C, SOULTOUKIS GA, NIEMEYER C, KERR F, PLETCHER SD, RIBEIRO C, PARTRIDGE L (2013). A holidic medium for Drosophila melanogaster. Nat Methods 11: 100

RAJAN A, PERRIMON N (2012). Drosophila cytokine unpaired 2 regulates physiological homeostasis by remotely controlling insulin secretion. Cell 151:123-137.

REWITZ KF, YAMANAKA N, GILBERT LI, O'CONNOR MB (2009). The insect neuropeptide PTTH activates receptor tyrosine kinase torso to initiate metamorphosis. Science 326: 1403-1405.

RICHHARIYA S, JAYAKUMAR S, ABRUZZI K, ROSBASH M, HASAN G (2017). A pupal transcriptomic screen identifies Ral as a target of store-operated calcium entry in Drosophila neurons. Sci Rep 7: 42586.

RIZZUTO R, DE STEFANI D, RAFFAELLO A, MAMMUCARI C (2012). Mitochondria as sensors and regulators of calcium signalling. Nat Rev Mol Cell Biol13: 566-578.

ROBERTSON FW (1963). The ecological genetics of growth in Drosophila 6. The genetic correlation between the duration of the larval period and body size in relation to larval diet. Genet Res 4: 74-92.

RODENFELS J, LAVRYNENKO O, AYCIRIEX S, SAMPAIO JL, CARVALHO M, SHEVCHENKO A, EATON S (2014). Production of systemically circulating Hedgehog by the intestine couples nutrition to growth and development. Genes Dev 28: 2636-2651.

RULIFSON EJ, KIM SK, NUSSE R (2002). Ablation of insulin-producing neurons in flies: growth and diabetic phenotypes. Science (80-) 296: 1118-1120.

SANO H, NAKAMURA A, TEXADA MJ, TRUMAN JW, ISHIMOTO H, KAMIKOUCHI A, NIBU Y, KUME K, IDA T, KOJIMAM (2015). The Nutrient-Responsive Hormone CCHamide-2 Controls Growth by Regulating Insulin-like Peptides in the Brain of Drosophila melanogaster. PLOS Genet 11: e1005209. 
SETIAWAN L, PAN X, WOODS AL, O\&\#039;CONNOR MB, HARIHARAN IK (2018). The BMP2/4 ortholog Dpp can function as an inter-organ signal that regulates developmental timing. Life Sci Alliance 1: e201800216.

SHAW PJ, FESKE S (2012). Physiological and pathophysiological functions of SOCE in the immune system. Front Biosci (Elite Ed) 4: 2253-2268.

SLAIDINA M, DELANOUE R, GRONKE S, PARTRIDGE L, LEOPOLD P (2009). A Drosophila insulin-like peptide promotes growth during nonfeeding states. Dev Cell 17: 874-884

SOMASUNDARAMA, SHUMAK, MCBRIDEHJ, KESSLERJA, FESKES, MILLERRJ, PRAKRIYAM (2014). Store-operated CRAC channels regulate gene expression and proliferation in neural progenitor cells. J Neurosci 34: 9107-9123.

STIEPER BC, KUPERSHTOK M, DRISCOLL M V., SHINGLETON AW (2008). Imaginal discs regulate developmental timing in Drosophila melanogaster. Dev Biol 321: 18-26.

SUBRAMANIAN M, METYA SK, SADAF S, KUMAR S, SCHWUDKE D, HASAN G (2013). Altered lipid homeostasis in Drosophila InsP3 receptor mutants leads to obesity and hyperphagia. Dis Model Mech 6: 734-44.

TAKEI K, SHIN RM, INOUE T, KATO K, MIKOSHIBA K (1998). Regulation of nerve growth mediated by inositol 1,4,5-trisphosphate receptors in growth cones. Science 282: 1705-1708.

TEOS LY, ZHANG Y, COTRIM AP, SWAIM W, WON JH, AMBRUS J, SHEN L, BEBRIS L, GRISIUS M, JANG S-I, YULE DI, AMBUDKAR IS, ALEVIZOS I (2015). IP3R deficit underlies loss of salivary fluid secretion in Sjogren's Syndrome. Sci
Rep 5: 13953.

TERRY LE, ALZAYADY KJ, FURATI E, YULE DI (2018). Inositol 1,4,5-trisphosphate Receptor Mutations associated with Human Disease. Messenger (Los Angeles, Calif Print) 6: 29-44.

TOTH AB, SHUM AK, PRAKRIYA M (2016). Regulation of neurogenesis by calcium signaling. Cell Calcium 59: 124-134.

VASHISHT A, TREBAK M, MOTIANI RK (2015). STIM and Orai proteins as novel targets for cancer therapy. A Review in the Theme: Cell and Molecular Processes in Cancer Metastasis. Am J Physiol Cell Physiol 309: C457-C469.

VENKATESH K, HASAN G (1997). Disruption of the IP3 receptor gene of Drosophila affects larval metamorphosis and ecdysone release. Curr Biol 7: 500-509.

VENKITESWARAN G, HASAN G (2009). Intracellular Ca2+ signaling and storeoperated Ca2+ entry are required in Drosophila neurons for flight. Proc Natl Acad Sci USA 106: 10326-10331.

WANG Y, LI G, GOODE J, PAZ JC, OUYANG K, SCREATON R, FISCHER WH, CHEN J, TABAS I, MONTMINY M (2012). Inositol-1,4,5-trisphosphate receptor regulates hepatic gluconeogenesis in fasting and diabetes. Nature 485: 128-132.

XU Y, BORCHERDING AF, HEIER C, TIAN G, ROEDER T, KÜHNLEIN RP (2019). Chronic dysfunction of Stromal interaction molecule by pulsed RNAi induction in fat tissue impairs organismal energy homeostasis in Drosophila. Sci Rep 9: 6989.

YAMANAKA N, MARQUES G, O'CONNOR MB (2015). Vesicle-Mediated Steroid Hormone Secretion in Drosophila melanogaster. Cell 163: 907-919. 
Further Related Reading, published previously in the Int. J. Dev. Biol.

A morphology-based assay platform for neuroepithelial-like cells differentiated from human pluripotent stem cells

Mika Suga, Hiroaki Kii, Naoko Ueda, Yu-Jung Liu, Takako Nakano, Tomoro Dan, Takayuki Uozumi, Yasujiro Kiyota and Miho K. Furue Int. J. Dev. Biol. (2018) 62: 613-621

https://doi.org/10.1387/ijdb.180161mf

Dictyostelium discoideum Sir2D modulates cell-type specific gene expression and is involved in autophagy

Rakhee Lohia, Punita Jain, Mukul Jain, Pradeep Kumar Burma, Anju Shrivastava and Shweta Saran

Int. J. Dev. Biol. (2017) 61: 95-104

https://doi.org/10.1387/ijdb.160038ss

Uterine glands: biological roles in conceptus implantation, uterine receptivity and decidualization

Justyna Filant and Thomas E. Spencer

Int. J. Dev. Biol. (2014) 58: 107-116

https://doi.org/10.1387/ijdb.130344ts

Decreased neoblast progeny and increased cell death during starvation-induced planarian degrowth

Cristina González-Estévez, Daniel A. Felix, Gustavo Rodríguez-Esteban and A. Aziz Aboobaker

Int. J. Dev. Biol. (2012) 56: 83-91

https://doi.org/10.1387/ijdb.113452cg

Co-localization of neural cell adhesion molecule and fibroblast growth factor receptor 2 in early embryo development

Liselotte Vesterlund, Virpi Töhönen, Outi Hovatta and Juha Kere

Int. J. Dev. Biol. (2011) 55: 313-319

https://doi.org/10.1387/ijdb.103240lv

Uteroplacental vascular development and placental function: an update

Lawrence P. Reynolds, Pawel P. Borowicz, Joel S. Caton, Kimberly A. Vonnahme, Justin S. Luther, David S. Buchanan, Shireen A. Hafez, Anna T. Grazul-Bilska and Dale A. Redmer Int. J. Dev. Biol. (2010) 54: 355-365

https://doi.org/10.1387/ijdb.082799/r

Trophoblast phagocytic program: roles in different placental systems

Estela Bevilacqua, Mara-Sandra Hoshida, Andrea Amarante-Paffaro, Andrea Albieri-Borges and Sara Zago-Gomes

Int. J. Dev. Biol. (2010) 54: 495-505

https://doi.org/10.1387/ijdb.082761eb
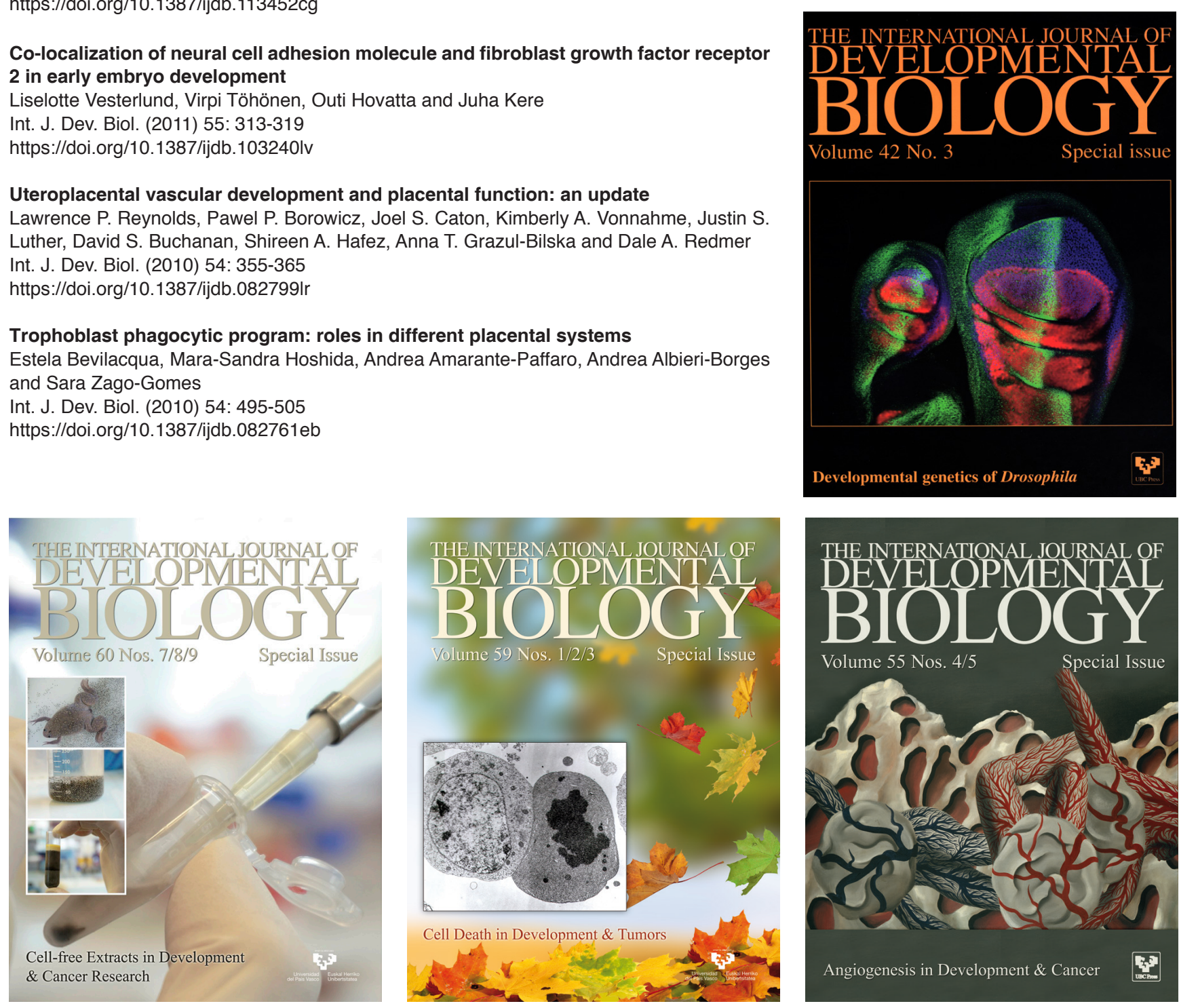